\title{
Evaluation of Sanitation Practices in Ibadan South East LGAs of Oyo State, Nigeria
}

\author{
Oke, M.O, \\ Atinsola, M.A \\ Aina, $M$.
}

Social Governance Policy Research Department Nigerian Institute of Social and Economic Research (NISER), Ibadan-Nigeria

\section{Doi:10.5901/ajis.2012.v2n5p79}

\section{Abstract}

Sanitation is paramount to human life because it contributes to safety from communicable and non-communicable diseases as well as playing important roles in human socio- economic development and sustenance of cultural values. The aim of this paper is to highlight unwholesome practices that are inimical to good sanitation in Nigeria with particular focus on Ibadan South East LGAs of the Metropolis. Survey method was largely used in this study with questionnaire administered on 233 respondents selected from 40 households spatially spread across the LGAs. The analysis shows that domestic liquid and solid wastes constitute environmental hazard in the area. About 69 per cent of the respondents are females which indicate that issue of household sanitation is gender biased, 64 per cent of respondents are married depicting large household size with multiplier effect on quantity of waste generated. Also 28.3 per cent of households pack solid waste in sacks while 24 per cent use waste bins. Also, 17.2 per cent dump and burn solid waste in front of houses while nine per cent dispose of refuse on vacant plots. The astonishing revelation is that 6.9 per cent of them throw waste into flowing streams while 12.9 per cent dump waste into drainage. Adding to these problems is lack of awareness of building code which made sanitary facilities wrongly located. Education through public enlightenment, provision of sanitary facilities and involvement of PPP among other things are advocated to remedying the present sanitation problems in Ibadan city and cities in Nigeria.

\subsection{Introduction}

Sanitation has been defined by different people and organisations as degree to which clean human environment is maintained. A more comprehensive definition, credited to the United Nations Educational Social and Cultural Organisation (UNESCO), states that sanitation is "Maintaining clean, hygienic circumstances that help to avoid diseases through services such as waste collection and disposal or recycling". In a similar perspective, the National Water Resources Management Policy (NWRMP) (2003) defines sanitation as dealing with the principles and practices relating to the collection, removal or disposal of human excreta, household waste water and refuse as they impact upon people and the environment. Good sanitation includes appropriate health and hygiene awareness and behaviour, acceptable and affordable as well as sustainable sanitation services. The basic level of environmental sanitation system must satisfy the following criteria: it must be associated with appropriate method for disposing human excreta as well as household waste water and refuse in a manner that is acceptable and affordable to the users; it must also be safe, hygienic, and easily accessible and must not have negative impact on the environment.

The problem of lack of good sanitation varies from place to place but it is more pronounced in the urban centres, especially in developing and under-developed countries. This problem is exacerbated by high population density which results in overcrowding, inadequate planning and poor urban governance (Ayeni, 1981, Agbola and Elijah, 2006, Onibokun and Kumuyi, 2007). The aim of this paper is to highlight some 
common practices that aggravate the precarious condition of sanitation in urban centres in Nigeria. The paper focuses on Ibadan South East areas in Ibadan Metropolis as a case study.

\subsection{The Study Area}

Ibadan is located on longitude $7^{\circ} 2^{\prime}$ and $7^{\circ} 40^{\prime} \mathrm{E}$ and latitude $3^{\circ} 35^{\prime}$ and $4^{\circ} 10^{\prime} \mathrm{N}$, the city was founded in 1829 . It was initially occupied by Yoruba immigrants, who sought refuge in the city while fleeing from intertribal wars. It is the largest indigenous city in tropical Africa; and it is the capital of Oyo State, Nigeria. As the crow flies, it is 128 kilometers $(\mathrm{km})$ northeast of Lagos and $345 \mathrm{~km}$ southwest of Abuja, the Federal Capital Territory (FCT). The city has grown particularly through the establishment of many institutions, construction of roads and the railway line. One of the institutions in the city is the University of Ibadan, the first university established in Nigeria. The convergence of the major trade routes (through Ijebu / Abeokuta, Lagos and Ilorin/Oyo) in Ibadan, coupled with the establishment of the railway, accelerated the growth of the city. European traders were attracted and granted leasehold to land in Ibadan in 1903. Today, five major roads and a motorway from Lagos radially converge in Ibadan. Most of southwestern Nigeria states (excluding the Lagos area) prefer Ibadan for the procurement of specialised goods and services.

The city has recorded rapid growth, both in land area and population. Developed land increased from only 100 hectares in 1830 to 12.5 square kilometres $\left(\mathrm{km}^{2)}\right.$ in $1931,30 \mathrm{~km}^{2}$ in $1963,112 \mathrm{~km}^{2}$ in 1973,136 $\mathrm{km}^{2}$ in 1981 , and $214 \mathrm{~km}^{2}$ in 1988 . Similarly, in 1856, the population was estimated at 60, 000; by 1890, it had increased to about 200, 000; in 1963, it was 625, 000; and almost 2.4 million at the moment (National Population Commission, 2009). Measured from the General Post Office in the central business district, the city has sprawled out to a radius of $12-15 \mathrm{~km}$ along the primary roads. The city's metropolitan region covers about 4, $200 \mathrm{~km}^{2}$, with boundaries varying from $17 \mathrm{~km}$ in the southwest to about $45 \mathrm{kms}$ in the northeast. It comprises 11 local government areas with five in the inner city and six in the outer areas. This paper focuses on sanitary practices in Ibadan metropolis with special attention to Ibadan South East area where field survey was done.

Ibadan South East Local Government with headquarters at Mapo was among five local government councils/areas carved out of Ibadan Municipal Government (IMG). It comprises 12 political wards (Table 1). It is made up of older residential districts located at the central area of the city. They are occupied largely by the indigenous Ibadan population and the early non-Ibadan Yoruba immigrants. Some of the districts in the area are stated in table 1 below.

The major sources of employment for the residents are mostly retail trade, public administration, service and repair industries, and educational services. The present features of sanitation practices in most parts of Ibadan city are: poorly-managed solid-waste and drainage, poor transportation facilities, inadequate public utilities and social infrastructure, poor housing conditions as well as foul odour. These issues have been compounded by political instability and absence of informed and effective political leadership (CASSAD, 1994).

Table 1: Ward and Residential Areas in Ibadan South East

\begin{tabular}{|c|l|c|c|l|}
\hline S/N & Ward & $\begin{array}{c}\text { Area } \\
\text { code }\end{array}$ & $\begin{array}{c}\text { No of } \\
\text { Localities }\end{array}$ & \multicolumn{1}{c|}{ Residential Areas Name } \\
\hline 1 & Ward & $\mathrm{C}_{1}$ & 6 & Mapo, Oke Dada, Ogunmola, Oja Oba, Oderinlo, Palace, \\
\hline 2 & Ward 2 & $\mathrm{S}_{1}$ & 6 & Oja Oba, Kure, Isale Jebu, Idi Arere, Omiyale, Ita Koto \\
\hline 3 & Ward 3 & $\mathrm{S}_{2} \mathrm{~A}$ & 6 & $\begin{array}{l}\text { OtunAgbaakin, Kobomoje, Oranyan, Kobiowu, Esuawele, } \\
\text { Temidire }\end{array}$ \\
\hline 4 & Ward 4 & $\mathrm{S}_{2} \mathrm{~B}$ & 3 & Kobomoje 2, Odo-Okun, Ogundepo \\
\hline
\end{tabular}




\begin{tabular}{|c|l|c|c|l|}
\hline 5 & Ward 5 & $\mathrm{S}_{3}$ & 5 & Labo Eleta, Olukoyi, Ita Ege, Idi Aro, Agbongbon \\
\hline 6 & Ward 6 & $\mathrm{S}_{4} \mathrm{~A}$ & 4 & Labo Elekuro, Asanike, Ayedaade, Tafa Adeoye \\
\hline 7 & Ward 7 & $\mathrm{S}_{4} \mathrm{~B}$ & 4 & Orita Aperin, Oniyere, Adesola, Tafa Adeoye 2 \\
\hline 8 & Ward 8 & $\mathrm{~S}_{5}$ & 3 & Odinjo, Eleta, Oyapidan \\
\hline 9 & Ward 9 & $\mathrm{S}_{6} \mathrm{~A}$ & 6 & $\begin{array}{l}\text { Oke Odo, Kudeti, Olunloyo, Adelabu's House, Adebi } \\
\text { Opon, Anirin, Kunfayakun }\end{array}$ \\
\hline 10 & Ward 10 & $\mathrm{S}_{6} \mathrm{~B}$ & 5 & Oke Oluokun, Oke Ola, Owode, Odo Oba, Sanyo \\
\hline 11 & Ward 11 & $\mathrm{S}_{7} \mathrm{~A}$ & 10 & $\begin{array}{l}\text { Oke Odo2, Molete, Idi Arere2, Kudeti, Yejide, Bode, Odo } \\
\text { Oba, Osungbade, Elere, Kerewu, Sanyo2 }\end{array}$ \\
\hline 12 & Ward 12 & $\mathrm{S}_{4} \mathrm{~B}$ & 6 & $\begin{array}{l}\text { Felele, Orita Challenge, Olorunsogo Scout Camp, Falana } \\
\text { petrol Station and Adelabu Shopping complex. }\end{array}$ \\
\hline
\end{tabular}

Source: Ibadan South East Local Government, Oyo State.

\section{Review of Literature}

This section contains desk research from previous studies and newspaper publications. Most studies reveal that domestic waste contributes greatly to the present unsanitary condition in Ibadan metropolis and it can be categorised into two, namely solid and liquid waste.

3.1 Solid Waste in Ibadan comprises leaves, paper, food waste, tins, glass, and rags (McLaren International Ltd, 1970). This is because Ibadan is located in the heart of a rich agricultural land and has a large old and unplanned section. In a comparative analysis of the composition of solid waste from two acres of Ibadan in 1970, PAI Associates (1983) shows that residential land use accounted for 70.1per cent of the waste generated, followed by commercial land use (18.8\%) and industrial land use (9.7\%). Institutional and other land use accounted for 0.7 per cent each. The mean percentage composition of solid waste in Ibadan in 1982 for different parts of the city shows that in the new areas (GRA, Bodija, Mokola and Sango), food remnants, tins and metals constituted the largest proportion of solid waste, whereas in the traditional areas (Agugu, Oja-oba and Oje) leaves and bones, ash dust, and stones constituted the bulk. The composition by weight of the various constituents of solid waste has also changed, with the leaves declining over time and while tins and metals, paper, and bones, ash dust and stones are increasing (Onibokun and Kumuyi, 2006). It is noteworthy that leaf waste particulates are now being replaced by cellophane waste materials. The adoption of new packaging system in the city (e.g. use of nylon bags and drinking of packaged water) is contributing to the huge amount of solid waste found across the city. However, data is not available on the amount of waste currently generated daily by the residents

3.2 Liquid Waste: Liquid waste in Ibadan also contains particles of corroded tins and iron, excreta, oil (red, fat, engine and lubricant), pieces of iron scrap, and other refuse. Outside of large institutions, such as the University College Hospital and State Hospital, Adeoyo, Ibadan has no sewerage. The city's human excreta are disposed off largely by means of septic tanks, pit latrines, and bucket; in some cases, it is wrapped with nylon and thrown into the gutter or stream. The uncontrolled disposal of liquid waste into open gutters, open spaces, and along roads poses serious environmental and health hazards. Bodies of stagnant water produce bad odour, breed mosquitoes, and sometimes obstruct the movement of people and goods. The 1983 study by PAI Associates reveals that 50 per cent of the stagnant pools emitted bad odour, 70 per cent bred mosquitoes, 24 per cent obstructed the movement of people, and 12 per cent bred worms and other germ-breeding pests. Poor practices of liquid-waste disposal are perhaps responsible for water-borne diseases occurring in the city, particularly in the areas constituting Ibadan South East (Plate 1). The unwholesome 
environment forces the populace to spend appreciable portions of their income and time on improving personal health, adverse consequences for general economic well-being.

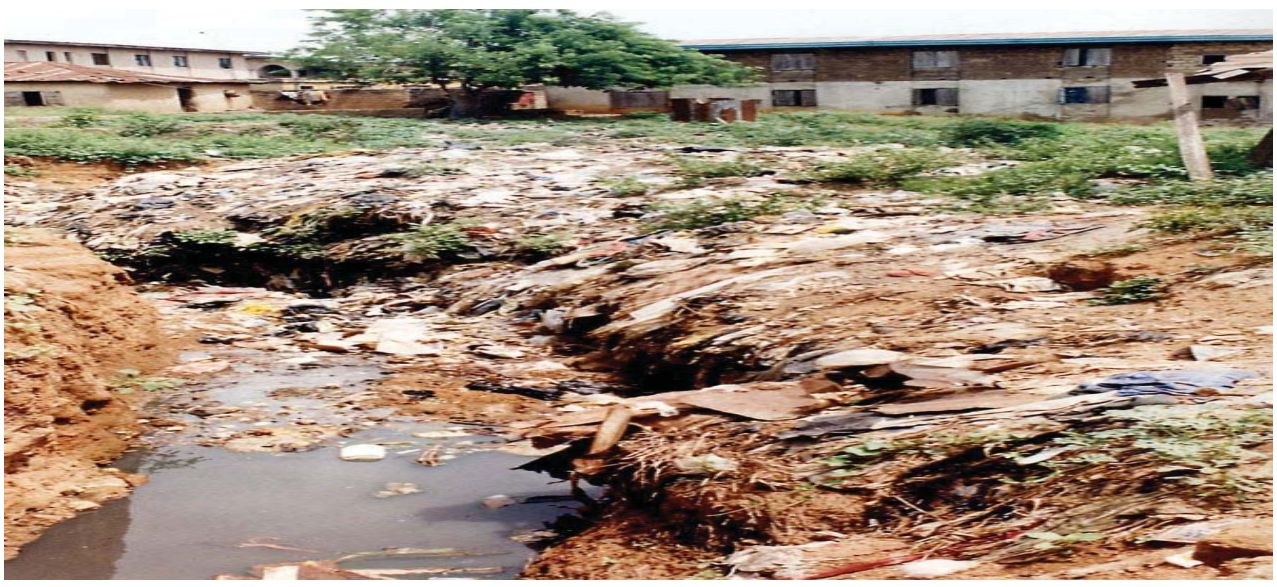

Source: Fieldwork, 2012.

Plate 1; Liquid waste in an open drainage channel in Idi-Arere, Ibadan.

\subsection{Data Source and Collection}

The focus of this paper is the analysis of sanitation practices by the residents of Ibadan South East Local Government Area of the metropolis. Primary and secondary data sources were utilised for this paper. The primary data was derived from a survey in which questionnaire was administered on selected resident households in the study area. Secondary data was derived from articles, textbooks and journals as well as documents from the Internet especially for concepts and theoretical issues as well as relevant information on global best sanitary practices.

\subsection{Sample Frame and Techniques}

Primary data utilised for this study was collected through questionnaire administration in selected localities within the study area. The sample was drawn from 64 localities that constitute Ibadan South East LGAs. The localities were delineated into 40 blocks in which 20 per cent of the total number of localities were selected for the study (Table 2). Stratified sampling technique was adopted and a total of 233 people were contacted with structured questionnaire.

Table 2: Selected Localities in Ibadan South East LGAs

\begin{tabular}{|c|c|c|l|}
\hline Block Numbers & Selected blocks & Number of localities & Name of Localities \\
\hline 1 & 3 & 1 & Felele \\
\hline 2 & 7 & 1 & Scout camp \\
\hline 3 & 11 & 1 & Sanyo \\
\hline 4 & 20 & 1 & Kudeti \\
\hline 5 & 25 & 3 & Odinjo,Eleta, Oyapidan \\
\hline
\end{tabular}




\begin{tabular}{|l|l|l|l|}
\hline 6 & 27 & 1 & Oja Oba \\
\hline 7 & 31 & 1 & Oke Dada \\
\hline 8 & 39 & 1 & Asanike \\
\hline
\end{tabular}

Source: Fieldwork, 2012.

\subsection{Data Analysis}

Descriptive and inferential statistical were used for the data analysis. These include using cross tabulations, charts and frequency distribution to summarise and describe the characteristics of the data as well as variations between different variables in the questionnaire. Chi-square was used for this analysis because the data involved were both in nominal and ordinal scales. Analyses of the amount of income, educational and occupational status as well as sex of respondents are some of the indicators that formed the basis for individual preferences for the quality of sanitation practiced by respondents.

\section{Results and Discussion}

\subsubsection{Sex and Age Distribution}

The result shows that 69.1 per cent of respondents are females while 30.9 per cent are males. It also shown that 41.2 per cent of the respondents are within the age group of 31-40 years while those within the age group of 41-59 years constitute 26.6 per cent and 20.6 per cent are within the age group of 18-30 years (Table 4.1). The large proportion of female respondents indicates that females are more concerned with the issue of sanitation practices than males in the selected areas. This confirms that females play a major role in environmental sanitation in our society; therefore any policy target at improving environmental practices must be take cognisance of this.

Table 3.1: Relationship between Age and Sex of Respondents

\begin{tabular}{|c|c|c|c|}
\hline \multirow{2}{*}{ Age -Group } & \multicolumn{2}{|c|}{ Sex } & \multirow{2}{*}{ Total } \\
\cline { 2 - 3 } & Male & Female & \\
\hline $18-30$ years & 19 & 29 & 48 \\
C\% & 26.4 & 18.0 & \\
R \% & 39.5 & 60.4 & 20.6 \\
\hline $31-40 y$ yrs & 22 & 74 & 96 \\
C \% & 30.6 & 46.0 & \\
R \% & 22.9 & 77.1 & 41.2 \\
\hline $41-59 y r s$ & 22 & 40 & 62 \\
C \% & 30.6 & 24.8 & 26.6 \\
R \% & 35.5 & 64.5 & 24 \\
\hline $60-69 y r s$ & 9 & 15 & 10.3 \\
C \% & 12.5 & 9.3 & \\
R \% & 37.5 & 62.5 & \\
\hline
\end{tabular}




\begin{tabular}{|c|c|c|c|}
\hline 70yrs and above & 0 & 3 & 3 \\
$\mathrm{C} \%$ & 0.0 & 1.9 & 1.9 \\
$\mathrm{R} \%$ & 0.0 & 100.0 & $\mathbf{2 3 3}$ \\
\hline & 72 & 161 & $\mathbf{1 0 0 . 0}$ \\
\hline
\end{tabular}

Source: Fieldwork, 2012.

\subsubsection{Marital Status and Age}

The result also reveals that 64.3 per cent of the respondents are married and 12.9 per cent are widows. Also, 51.3 per cent of married respondents are within ages of 31-40 years while 28.0 per cent are within 41-59 years and 14.0 per cent are within 18-40 years. Further analysis indicates that there is significant relationship between the age group and marital status (chi-square value of $0.000 ; \mathrm{p}<0.05$ ). This implies that a significant proportion of respondents are married and this has an implication on the household size. Large household size perhaps will have multiplier effect on the amount of waste generated per household in the area (Table 3.2).

Table 3.2 Marital Status and Age Group of Respondents

\begin{tabular}{|c|c|c|c|c|c|c|}
\hline \multirow{2}{*}{ Marital status } & \multicolumn{5}{|c|}{ Age } & \multirow[b]{2}{*}{ Total } \\
\hline & $18-30 \mathrm{yrs}$ & $31-40$ yrs & $41-59$ yrs & $60-69$ yrs & 70 yrs + & \\
\hline Single & 24 & 4 & 0 & 0 & 0 & 28 \\
\hline $\mathrm{C} \%$ & 50.0 & 4.2 & 0.0 & 0.0 & 0.0 & \\
\hline $\mathrm{R} \%$ & 85.7 & 14.3 & 0.0 & 0.0 & 0.0 & 12.0 \\
\hline Married & 21 & 77 & 42 & 10 & 0 & 150 \\
\hline $\mathrm{C} \%$ & 43.8 & 80.2 & 67.7 & 41.7 & 0.0 & \\
\hline $\mathrm{R} \%$ & 14.0 & 51.3 & 28.0 & 6.7 & 0.0 & 64.3 \\
\hline Divorced & 2 & 5 & 6 & 1 & 0 & 14 \\
\hline $\mathrm{C} \%$ & 4.2 & 5.2 & 9.7 & 4.2 & 0.0 & \\
\hline $\mathrm{R} \%$ & 14.3 & 35.7 & 42.9 & 7.1 & 0.0 & 6.0 \\
\hline Widowed & 0 & 7 & 9 & 11 & 3 & 30 \\
\hline $\mathrm{C} \%$ & 0.0 & 7.3 & 14.5 & 45.8 & 100.0 & \\
\hline $\mathrm{R} \%$ & 0.0 & 23.3 & 30.0 & 36.7 & 0.0 & 12.9 \\
\hline Widower & & 1 & 2 & 2 & 0 & 5 \\
\hline $\mathrm{C} \%$ & 0 & 1.0 & 3.2 & 8.3 & 0.0 & \\
\hline $\mathrm{R} \%$ & & 20 & 40.0 & 40.0 & 0.0 & 2.1 \\
\hline Single parent & 1 & 2 & 3 & 0 & 0 & 6 \\
\hline $\mathrm{C} \%$ & 2.1 & 2.1 & 4.8 & 0.0 & 0.0 & \\
\hline $\mathrm{R} \%$ & 16.7 & 33.3 & 50.0 & 0.0 . & 0.0 & 2.6 \\
\hline Column & 48 & 96 & 62 & 24 & 3 & 233 \\
\hline Total & 20.6 & 41.2 & 26.6 & 10.3 & 1.3 & 100.0 \\
\hline
\end{tabular}

Source: Fieldwork, 2012. 


\subsubsection{Types of Occupation}

This study shows that trading (39.1\%) is the predominant occupation of the respondents in the study area, followed by artisanal activities (31.8\%). Other occupations of significant proportion are civil service $(23.6 \%)$ and farming (3.9\%). Traders and artisans generate a great deal of solid and liquid waste in the urban setting like the study area. The traders are mostly street vendors and lack the etiquette of disposing waste properly. Dumping waste indiscriminately is a common practice in Ibadan South East LGAs. Also, auto-mechanics, carpenters and other artisans constitute environmental nuisance in this areas. Again, it was observed that some respondents (those in the category of other artisans) engage in cassava-based gari and fufu processing, palm oil processing, and cloth weaving among others. These categories also generate a lot of solid and liquid waste and the manner in which they dispose the waste is inimical to the environment.

\subsubsection{Level of Education, Income and Types of Occupation}

The result also indicates that respondents with secondary education constitute 37.3 per cent, those with no education account for 25.6 per cent while those with tertiary education amount to 37.1 per cent. The high proportion of illiterates and low education people in the area impinges on the method and quality of sanitation practices. Education plays an important role in the enlightenment of people not only on personal hygiene but also on good sanitary practices. The level of income is one of the factors that determine where and how people live as well as the quality of sanitation facilities in homes. The result of this investigation indicates that about 40 per cent of the respondents earn between N5, $000-\mathrm{N} 15,000$ monthly incomes, and 33.5 per cent have income between N15, 000 -- N25, 000 while 6.9 per cent receive N35, 000 and above. With this and the types of occupation of the residents of these areas, it is evident that they are mostly lowincome earners (Table 3.3). Income affects accessibility to health facilities as low-income earners may not be able to afford modern sanitation facilities like flush toilet.

Table 3.3: Monthly Income and Types of Occupation

\begin{tabular}{|c|c|c|c|c|c|c|}
\hline \multirow{2}{*}{$\begin{array}{l}\text { Monthly } \\
\text { Income }\end{array}$} & \multicolumn{5}{|c|}{ Occupational Status } & \multirow[b]{2}{*}{ Total } \\
\hline & Farming & Trading & Artisan & Civil Servant & Others & \\
\hline$<\mathrm{N} 5000$ & 0 & 7 & 3 & 2 & 0 & 12 \\
\hline $\mathrm{C} \%$ & 0.0 & 7.7 & 4.1 & 3.6 & 0.0 & \\
\hline $\mathrm{R} \%$ & 0.0 & 58.3 & 25.0 & 16.7 & 0.0 & 5.2 \\
\hline N5001-15000 & 2 & 37 & 40 & 12 & 2 & 93 \\
\hline $\mathrm{C} \%$ & 22.2 & 40.7 & 54.1 & 21.8 & 50.0 & \\
\hline $\mathrm{R} \%$ & 2.2 & 39.8 & 43.0 & 12.9 & 2.2 & 39.9 \\
\hline N15001-25000 & 3 & 31 & 23 & 21 & 0 & 78 \\
\hline $\mathrm{C} \%$ & 33.3 & 34.1 & 31.1 & 38.2 & 0.0 & \\
\hline $\mathrm{R} \%$ & 3.8 & 39.7 & 29.5 & 26.9 & 0.0 & 33.5 \\
\hline $\mathrm{N} 25001-35000$ & 3 & 14 & 6 & 11 & 0 & 34 \\
\hline $\mathrm{C} \%$ & 33.3 & 15.4 & 8.1 & 20.0 & 0.0 & \\
\hline $\mathrm{R} \%$ & 8.8 & 41.2 & 17.6 & 32.4 & 0.0 & 14.6 \\
\hline N3500+ & & 2 & 2 & 9 & & 16 \\
\hline $\mathrm{C} \%$ & 11.1 & 2.2 & 2.7 & 16.4 & 50.0 & \\
\hline & 6.3 & 12.5 & 12.5 & 56.3 & 12.5 & 6.9 \\
\hline
\end{tabular}




\begin{tabular}{|c|c|c|c|c|c|c|}
\hline $\begin{array}{c}\text { Column } \\
\text { Total }\end{array}$ & 9 & 91 & 74 & 55 & 4 & 233 \\
\hline
\end{tabular}

Source; Author's Fieldwork, 2011.

\subsubsection{Availability of Sanitation Facilities}

Reconnaissance study of the Ibadan South East area shows that most of the residential houses are in form of bungalows and storey buildings with face-to-face rooms, and flats. The result of the analysis shows that 84 per cent of the respondents have kitchen, 71.2 per cent have toilet while 87.6 per cent claim to have bathroom in their houses. Also, 68.2 per cent assert that they have open gutter around their houses and 42.9 per cent have waste bin within their premises. However, fewer proportion (15.9\%) do not have kitchen, 28.8 per cent do not have toilet and 12.4 per cent of the respondents do not have bathroom. For 31.8 per cent of the respondents, there is no gutter and 57.1 per cent also stated that there are no waste disposal facilities in their houses (Table 4.1).

The foregoing shows that most of the respondents claimed to have sanitation facilities but physical observation shows that these facilities are in poor condition and cannot promote healthy living. Most bathrooms and kitchens in the areas are made of zinc sheets located at the back of houses, while pit latrine is the commonest toilet facility in these areas. It was discovered that residents dump their wastes and excreta into available drainage channels in the area especially residents of houses that have no toilet facility (Plate 2). It can be asserted from the result that sanitation practices in the study area are unwholesome. Apart from this, the physical layout of the area was badly planned. Most streets are exposed to bad environmental factors such as bad odour, indiscriminate waste dumps, and stagnant pools of sewage in drainages. This type of environment not only promotes outbreak of diseases but also impairs the health of the residents.

Table 4.1: Availability of Household Sanitation Facilities

\begin{tabular}{|c|c|c|c|c|c|c|c|c|c|c|c|c|}
\hline \multirow{2}{*}{ Facilities } & \multicolumn{2}{|c|}{ Kitchen } & \multicolumn{2}{|c|}{ Toilet } & \multicolumn{2}{|c|}{ Bathroom } & \multicolumn{2}{|c|}{$\begin{array}{c}\text { Water } \\
\text { Storage } \\
\text { Facility }\end{array}$} & \multicolumn{2}{|c|}{ Gutter } & \multicolumn{2}{|c|}{ Waste Bin } \\
\hline & No & $\%$ & No & $\%$ & No & $\%$ & No & $\%$ & No & $\%$ & No & $\%$ \\
\hline Available & 196 & 84.1 & 166 & 71.2 & 204 & 87.6 & 233 & 100.0 & 159 & 68.2 & 100 & 42.9 \\
\hline Not Available & 37 & 15.9 & 67 & 28.8 & 29 & 12.4 & 0.0 & 0.0 & 74 & 31.8 & 133 & 57.1 \\
\hline Total & 233 & 100.0 & 233 & 100.0 & 233 & 100.0 & 233 & 100.0 & 233 & 100.0 & 233 & 100.0 \\
\hline
\end{tabular}

Source: Fieldwork, 2012. 


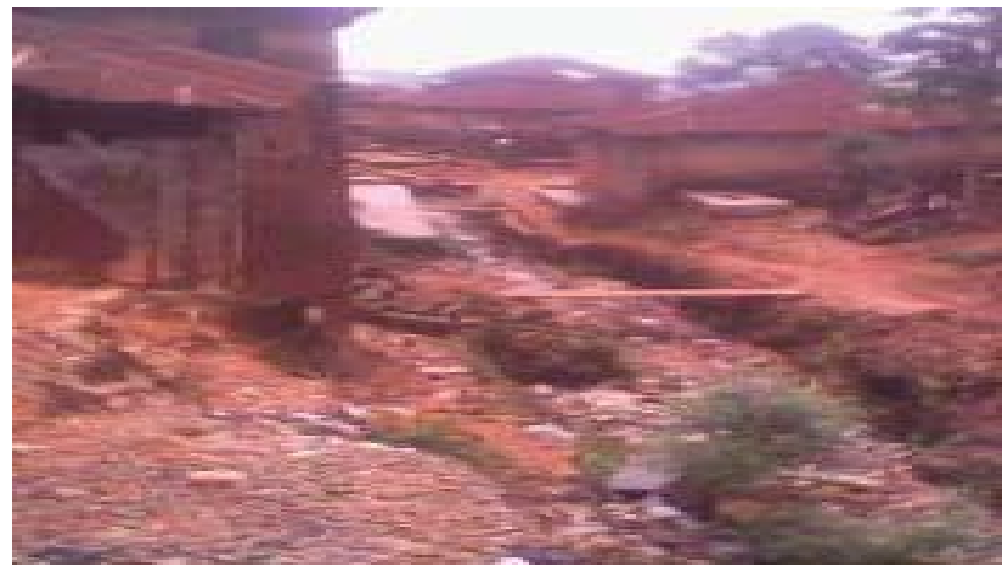

Plate 2: Kitchen and toilet located at the back of a house close to sewage channel in Odinjo, Ibadan.

\subsubsection{Method of Solid Waste Disposal}

Analysis of method of solid waste disposal in the study area shows that 28.3 per cent of the respondents pack their solid waste in sacks while 24 per cent use waste bins. This practice is common in areas like Felele, Sanyo, and Scout Camp as well as Oja - Oba. Also, 17.2 per cent dump and burn their solid waste in front of their houses while nine per cent dispose of their refuse on vacant plots (open spaces) or inside uncompleted houses in the area. The more astonishing revelation is that 6.9 per cent of the respondents confessed to dumping their solid waste into flowing streams while 12.9 per cent dump waste into drainage channels in their respective areas. These practices do not only constitute environmental hazard but are also capable of provoking natural disaster such as flooding as it happened in parts of the city in 2011 ( Plate 3 and figure 1).

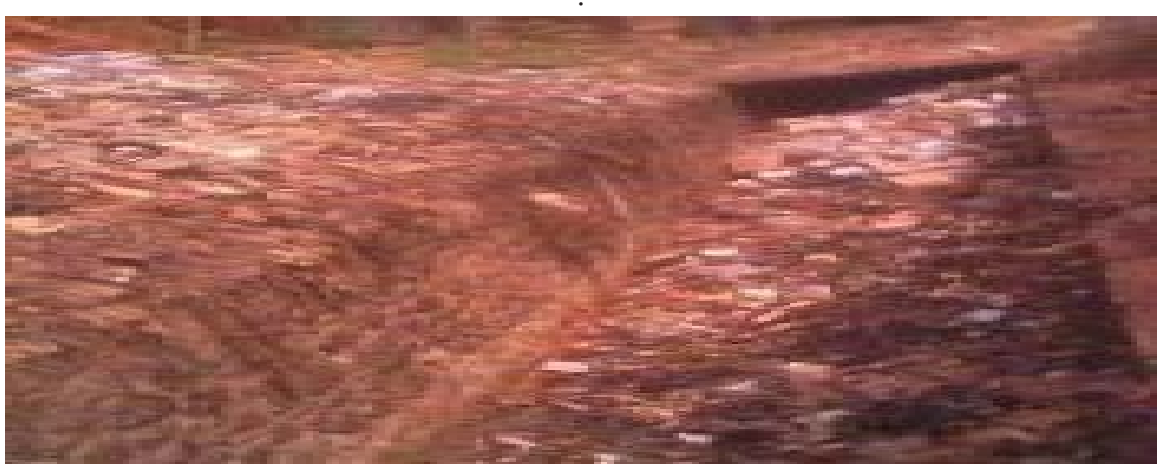

Source: Fieldwork, 2012.

Plate 3 Solid waste dumped into drainage channel at Oja Oba Area, Ibadan.

\subsubsection{Regularity of Cleaning Household Sanitation Facilities}

The analysis on the regularity of cleaning household sanitation facilities reveal that 1.7 per cent of the respondents clean their gutters and waste bins daily, while 9.0 per cent do same weekly. Also, 19.3 per cent 
carry out cleaning of gutter once in a month while 21.9 per clean their waste bins monthly. This implies that respondents' rate of cleaning household sanitation facilities is very low, further confirming that sanitation practice in the study area is poor and detrimental to clean and healthy environment (Figure 1).

\section{Methods of Collecting and Disposing Solid Waste}

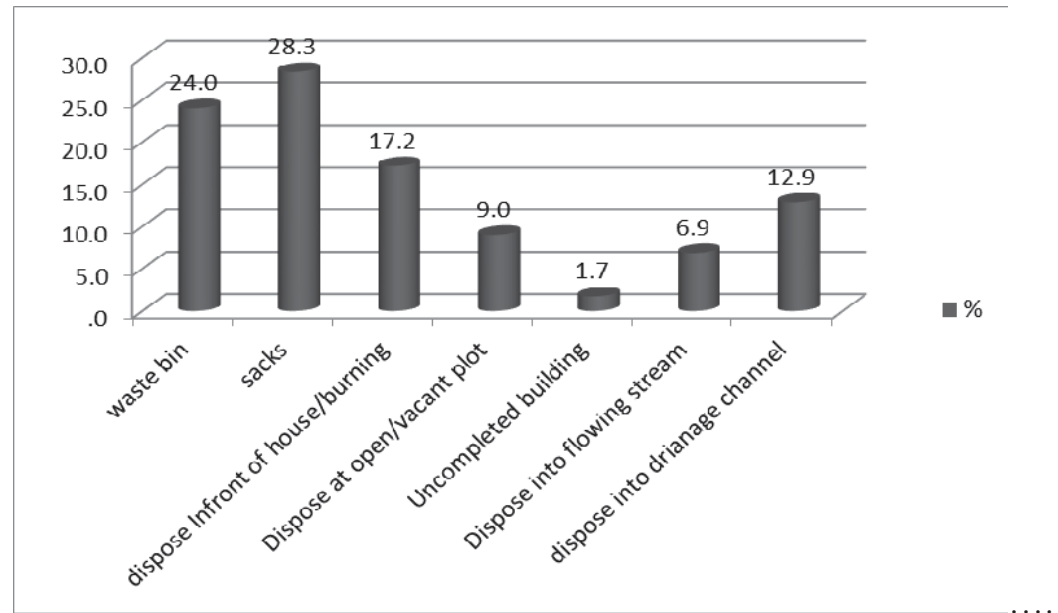

Figure 1. Source: Fieldwork, 2012.

\subsubsection{Method of Liquid Waste Disposal}

Analysis also shows that inhabitants of Ibadan South East LGAs adopt various methods of disposing liquid waste. About 61 per cent of the respondents discharge their liquid waste into the open gutter, 35 per cent dump their liquid waste outside their houses while six per cent dispose their liquid waste into available drainage channels in their area. This situation is disgusting in areas like Oja Oba, Idi Arere and Molete as well as Oke Dada.

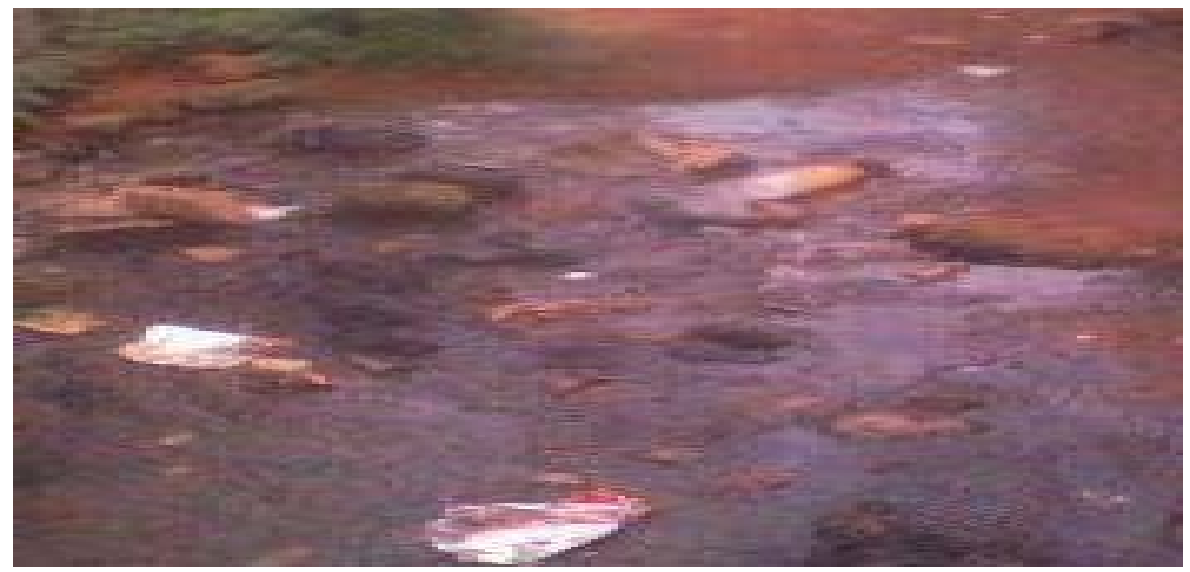

Plate 4: Liquid waste disposed outside a house in Oke Dada area, Ibadan 
It is obvious why most drainage channels are filled and blocked with solid wastes, which restrict the free flow of liquid waste or water which drainage channels are meant for. As a result, these channels emit bad odour and serve as breeding grounds for mosquitoes and flies which are vectors for bacterial infections that cause diseases like cholera and malaria.

\subsubsection{Location of Household Sanitation Facilities}

This section highlights the location of sanitation facilities within houses as currently practiced by the residents in most parts of the city. The aim is to further highlight practices that are detrimental to healthy environment and that may jeopardise attainment of Millennium Development Goals (MDGs) in health sector by 2020. Result of the analysis shows that 24.5 per cent of toilets are located close to kitchens and 35.6 per cent of bathrooms are close to kitchens. This pattern of location of household facilities is particularly common in tenement houses in the study area where kitchens, toilets and bathrooms are located very close to one another. 5.2 per cent of water storage facilities are placed very close to toilets due to inadequate space, although some respondents claimed to use such water for bathing and washing. 26.6 per cent of waste disposal facilities are located close or inside the kitchens for easy disposal of wastes. 11.6 per cent of gutters are located close to kitchen; this is common in Oja Oba, Oke-Dada, Eleta, Odinjo and Idi-Arere as well as Molete area. Also, 10.7 per cent of the bathrooms are close to water well, these bathrooms are usually made of zinc sheets or wood as illustrated in Plate 5. The location of sanitation facilities in close proximity to one another constitutes an environmental hazard. The implications are bad odour, food contamination, and breeding of mosquitoes, cockroaches and flies all over the place. Underground water pollution as a result of closeness of well to toilets and boreholes close to toilets is a part of the consequences of this badly planned actions (Figure 2).

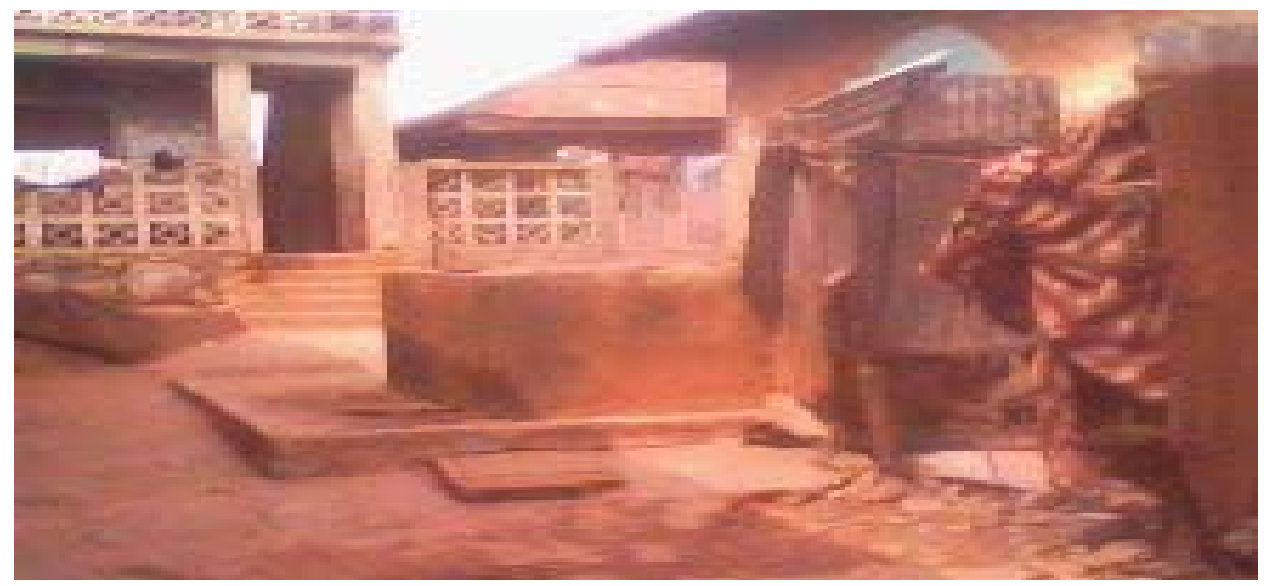

Plate 5 Bathroom made with zinc sheet and latrine located close to a well in Eleta Area, Ibadan.

Source: Fieldwork, 2012. 


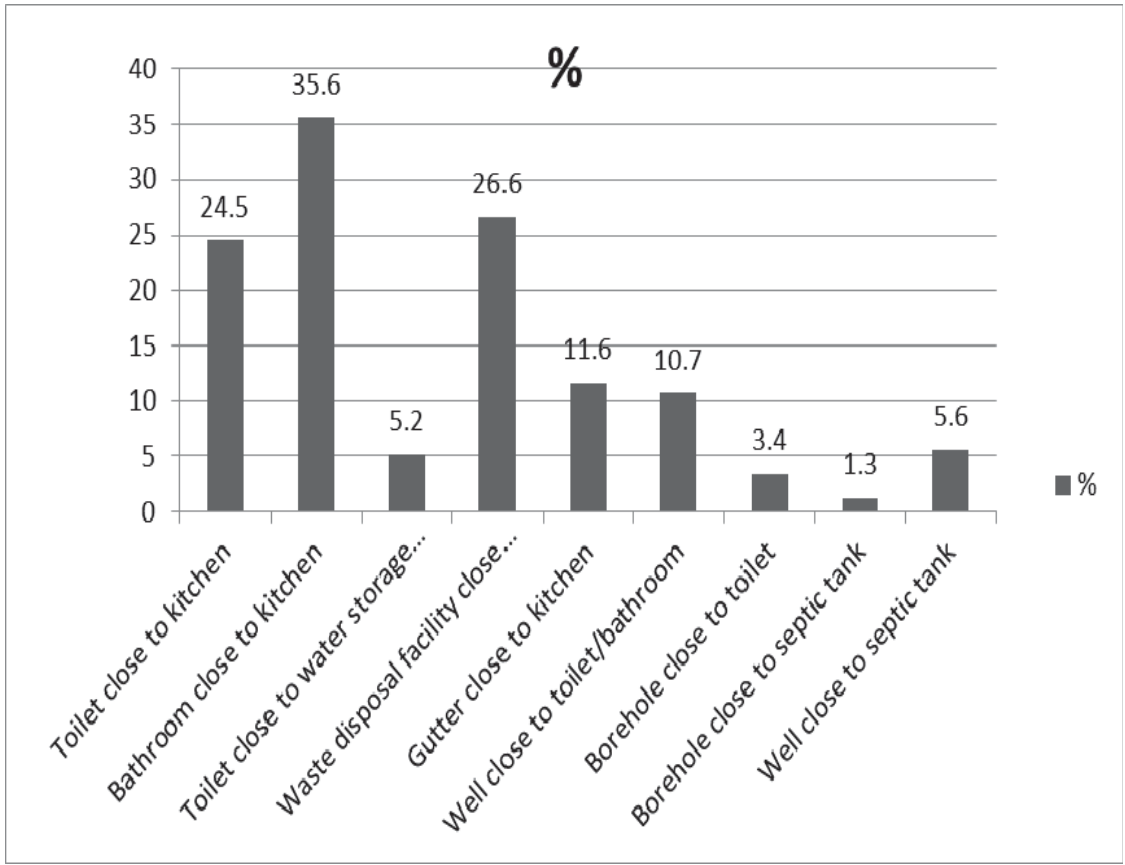

Figure 2: Locations of household sanitation facilities in residential buildings Source: Fieldwork, 2012.

\subsubsection{Perceptions on Location of Sanitation Facilities and Implications for Health}

This section utilised Likert scale to ascertain level of agreement of respondents on the location of household sanitation facilities in residential buildings and the implications to health. The responses are examined by comparing the mean (x) with the weighted value (X). Responses are categorised into six levels of agreement in order to calculate Respondents Agreement Index (RAI). Nine poser questions (variables) were used to determine the level of agreement on the location of household sanitation facilities. The greater the respondents' satisfactory index compared to the mean, the greater the level of agreement.

From Table 4.2, the level of agreement of respondents on location of toilets close to water storage facilities (5.79) and toilets close to kitchens (5.75) is strong and the weighted mean is greater than mean value $(x=4.98)$. This wrong perception of people is responsible for unhygienic location of these facilities and perhaps the cause of environmental problems in the affected areas. It was also discovered that respondents strongly agree that location of well close to toilets /bathrooms (5.45), gutter close to kitchens (5.28) and location of waste-disposal facilities close to kitchens (5.26) may lead to high incidence of water-related health problems such as typhoid fever, dysentery, diarrhoea, and cholera. However, responses on location of well close to septic tank (4.97), borehole close to toilet (3.79) and borehole to septic tank (3.49) recorded decrease in weighted value compared to the mean value. This implies that respondents believe that location of these facilities close one another had no health implications. The calculated RAI variance is $(0.70)$ with a Standard Deviation of (0.84) against a Co-efficient of Variation (16.86). It can be deduced from the result that location of these facilities close to another are detrimental to health of the residents in these areas (Table 4.2 and page 19 for details). 
Table 4.2 Perceptions on Location of Household Sanitation Facilities in Residential Building

\begin{tabular}{|c|c|c|c|c|c|c|c|c|c|c|c|}
\hline \multirow[b]{2}{*}{ Level of Agreement } & \multicolumn{6}{|c|}{ Respondents' opinion } & \multirow{2}{*}{$\begin{array}{c}\text { No } \\
\text { Respond } \\
\text { ents }\end{array}$} & \multirow[b]{2}{*}{ SWV(a) } & \multirow{2}{*}{$\begin{array}{c}\text { RAI } \\
\text { a } / 233\end{array} \mid$} & \multirow[b]{2}{*}{$\mathbf{x}-\mathbf{x}$} & \multirow[b]{2}{*}{$(x-x)^{2}$} \\
\hline & 6 & 5 & 4 & 3 & 2 & 1 & & & & & \\
\hline Toilet close to kitchen & 1122 & 170 & 48 & 0 & 0 & 0 & 233 & 1340 & 5.75 & 0.77 & 0.59 \\
\hline Bathroom close to kitchen & 702 & 170 & 256 & 54 & 0 & 0 & 233 & 1182 & 5.07 & 0.99 & 0.98 \\
\hline Toilet close to water storage & 1158 & 165 & 28 & 0 & 0 & 0 & 233 & 1351 & 5.79 & 0.81 & 0.66 \\
\hline $\begin{array}{l}\text { Waste disposal close to } \\
\text { kitchen }\end{array}$ & 780 & 215 & 208 & 21 & 2 & 0 & 233 & 1226 & 5.26 & 0.28 & 0.08 \\
\hline Gutter close to kitchen & 804 & 220 & 168 & 36 & 2 & 0 & 233 & 1230 & 5.28 & 0.30 & 0.09 \\
\hline $\begin{array}{l}\text { Well close to } \\
\text { toilet/bathroom }\end{array}$ & 804 & 375 & 80 & 12 & 0 & 0 & 233 & 1271 & 5.45 & 0.47 & 0.22 \\
\hline Borehole close to toilet & 462 & 280 & 52 & 0 & 0 & 87 & 233 & 881 & 3.78 & 1.20 & 1.44 \\
\hline $\begin{array}{l}\text { Borehole close to septic } \\
\text { tank }\end{array}$ & 396 & 270 & 40 & 6 & 0 & 101 & 233 & 813 & 3.49 & 1.49 & 2.22 \\
\hline Well close to septic tank & 762 & 285 & 80 & 3 & 0 & 28 & 233 & 1158 & 4.97 & -0.01 & 0.00 \\
\hline Total & & & & & & & & & 44.84 & & 6.28 \\
\hline
\end{tabular}

6--Strongly Agree, 5--Agree, 4--Somewhat Agree, 3--Disagree, 2--Strongly Disagree, 1--No Response.

Source: Fieldwork, 2012.

Likert Scale

Calculation for level of agreement on location of household facilities

RAI $=$ Respondents Agreement Index

SWV $=$ Sum of Weighted Value

NR $=$ No of Respondents

$\mathrm{N}=$ Total Number or Variables

$\sum \underline{(\mathrm{SWV})}=\mathrm{RAI}$

$$
\text { NR }
$$

$\mathrm{x}=\sum \underline{\mathrm{SWV}}$

$$
\frac{44.84}{9}=4.98
$$

Variance $\left.\left(S^{2}\right)=\sum \underline{(x-m e a n}\right)^{2} \quad=\underline{6.28} \quad=0.70$

$$
\mathrm{N} \quad 9
$$

Standard Déviation (S.D) $=V_{\text {variance }}=\sqrt{0.70}=0.84$

Co-efficient of variation $=\underline{\text { S D }} \times 100 \%=0.84 \quad$ X $100=16.86$

$$
\text { Mean } \quad 4.98
$$

Calculation for level of agreement to location of household facilities

$\mathrm{RAI}=$ Respondents Agreement Index

SWV $=$ Sum of Weighted Value

NR $=$ No of Respondents

$\mathrm{N}=$ Total Number of Variables

$\sum(\underline{S W V})=$ RAI 


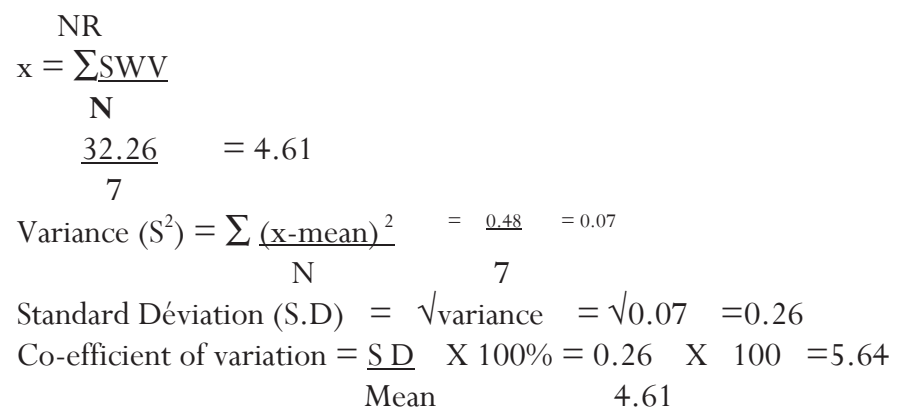

\subsubsection{Perceptions on Environment-related Diseases}

Findings from the study area reveal that there has been high incidence of water-related diseases. In actual fact, $88.8 \%$ of the respondents have suffered from one form of water related diseases such as typhoid, cholera, diarrhea, dysentery, skin rashes and malaria. Another $11.2 \%$ stated that they had not suffered from any form of diseases before. The high incidence of water-related diseases can be linked to poor quality of sanitation practices in the area (Figure 3).

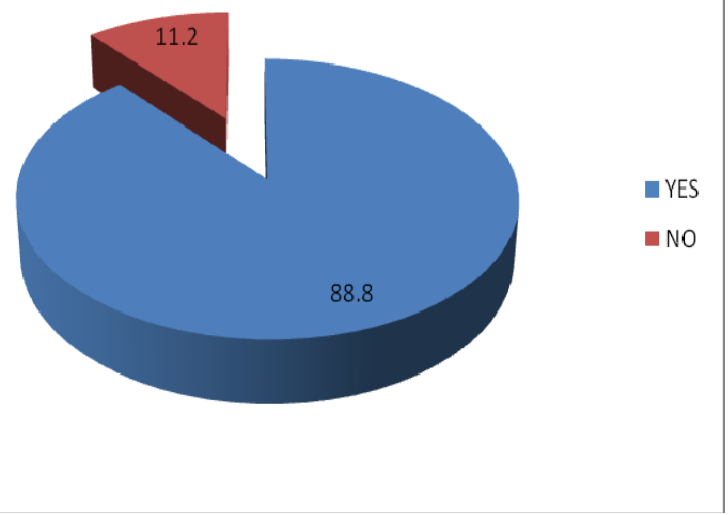

Source: Author's Fieldwork, 2012.

Figure 3: Respondents suffered from domestic water-related diseases

\subsection{Environment-related Diseases and Rate of Occurrence}

Results of analysis as summarised in Table 4.20 reveals that the bulk of the respondents had suffered from water borne disease. Another 0.9 per cent had suffered from diarrhoea weekly, 13.7 per cent monthly, and 18.9 per cent quarterly; in all cases, infants were the most vulnerable. Those that had suffered from typhoid fever constitute 3.4 per cent for quarterly and 42.1per cent yearly. Also, 12 per cent of the respondents had suffered from cholera before and 6.4 per cent suffered from dysentery yearly, while 12 per cent experienced dysentery monthly. Those that suffered from scabies account for 1.3 per cent quarterly and 0.9 per cent yearly while 21.5 per cent experienced skin rashes during dry season when water supply is inadequate. About 
4.7 per cent suffered from guinea worm infection in the last one year. Malaria is the most frequent disease in the area. And analysis reveals that 0.9 per cent of the respondents suffered from the disease monthly while 54.5 per cent had it quarterly and 23.6 per cent experienced it yearly. This can be linked to poor environmental condition of the area which refers to mountains of solid wastes, dirty gutters and drainage channels that serve as breeding grounds for mosquitoes and flies.

Table 4.3: Environment-related Diseases and Rate of Occurrence in the Area

\begin{tabular}{|c|c|c|c|c|c|c|c|c|}
\hline \multirow[t]{3}{*}{ Diseases } & \multicolumn{8}{|c|}{ Rate of Occurrence } \\
\hline & \multicolumn{2}{|c|}{ Weekly } & \multicolumn{2}{|c|}{ Monthly } & \multicolumn{2}{|c|}{ Quarterly } & \multicolumn{2}{|c|}{ Yearly } \\
\hline & No & $\%$ & No & $\%$ & No & $\%$ & No & $\%$ \\
\hline \multicolumn{9}{|l|}{ Water-borne } \\
\hline Diarrhoea & 2 & 0.9 & 32 & 13.7 & 44 & 18.9 & - & - \\
\hline Typhoid fever & - & - & - & - & 8 & 3.4 & 98 & 42.1 \\
\hline Cholera & - & - & - & - & - & - & 28 & 12.0 \\
\hline Dysentery & - & - & 28 & 12.0 & 47 & 20.0 & 15 & 6.4 \\
\hline \multicolumn{9}{|c|}{ Water washed or water scarce } \\
\hline Scabies & - & - & - & - & 3 & 1.3 & 2 & 0.9 \\
\hline Skin rashes & - & - & 9 & 3.9 & 32 & 13.7 & 50 & 21.5 \\
\hline \multicolumn{9}{|l|}{ Water based } \\
\hline Schistosomiasis & - & - & - & - & - & - & - & - \\
\hline Guinea worm & - & - & - & - & - & - & 11 & 4.7 \\
\hline \multicolumn{9}{|c|}{ Water-related insect vector } \\
\hline Dengue & - & - & - & - & - & - & - & - \\
\hline Malaria & - & - & 2 & 0.9 & 127 & 54.5 & 55 & 23.6 \\
\hline Trypanosomiasis & - & - & - & - & - & - & - & - \\
\hline
\end{tabular}

Fieldwork, 2012.

\section{Summary}

1) Level of awareness on good sanitation practices especially regular cleaning exercise is very low because populace are not concerned with environmental issues and that is why dumping waste indiscriminately is a common practice in the study area.

2) The problem of poor maintenance culture on the part of inhabitants as many waste disposal bins and other sanitary facilities have been damaged and not functioning.

3) Governments at federal, state and local levels have withdrawn from provision of waste-disposal bins for the populace.

4) The manpower, administrative structure and capital required for efficient disposal of refuse are grossly inadequate in the urban centre especially in Ibadan South East Area of the Metropolis.

5) Administrative personnel are corrupt and do not act transparently in terms of procurement of waste-disposal bins and other waste disposal facilities as well as no regular payment of salary to staff especially the street sweepers. 


\section{Recommendations}

1) There should be increase in the level of awareness on good sanitation practices and exercise for general populace. Governments should provide public enlightenment and education on proper maintenance culture within our environment.

2) Government at different levels must wake up to their responsibilities in terms of providing wastedisposal bins and other sanitation facilities for the people.

3) A functional administrative structure must be put in place for efficient disposal of refuse. And building plan must implemented according to approval given by the planning authority.

4) Efforts should be put in place for workable solution for solid waste disposal problems through involvement of private partnership programme (PPP).

5) Efforts should also be put in place to ensure transparency and accountability among personnel in charge of waste management in Nigeria.

\section{Conclusion}

Sanitation is paramount to human life because it contributes to safety from communicable and noncommunicable diseases as well as plays important roles in economic development and sustenance of cultural values. As a vital component of individual life, the availability, affordability, management and utilisation of sanitation exerts serious impacts on societal well-being and urban growth. Adequate provision of wastedisposal bins and related facilities should be the focal point of government policies and programmes in order to meet the sanitation demands of the people. In order to achieve this, government policies and programmes on availability of sanitation facilities need to be safeguarded against corruption and mismanagement of funds meant for the project. If the measures stated above are successfully implemented, the problems militating against good sanitation in Ibadan South East Local Government Area and Nigeria in general would be alleviated.

\section{References}

Caincross .S. O'nell, D, Mc coy; A and Selhi. D (2003) Health Environment and the Burden of Disease, A Guidance Note, Development for International Development, London

Fabiyi, O.O (2006). Urban Land Use Change Analysis of a Traditional City from Remote Sensing Data: The Case of Ibadan Metropolitan Area, Nigeria. Human and Social Sciences Journal 1(1); 42-64; 2006 IDOSI Publication.

Fourchard, L (2003). Managing Urban Waste: The Case of Ibadan, Nigeria. Institute Francais de Recherche en Afrique (IFRA), University of Ibadan.

Nigerian Environmental Study Action Team (NEST, 1991) Nigeria's Threatened Environment. A National Profile. NISER, Ibadan.

Oke, M.O (2012). Rapid Urban In-migration and Environmental Nuisance in Nigerian Cities: The Case of Street Vending in Lagos City. Sustainable Environmental Planning and Management in Nigeria; Urban and Regional Planning Department, Ladoke Akintola University, Ogbomoso, Nigeria.

Onibokun, A.G (2003). Governance of Waste Management in Ibadan: Geographical Characteristics. International Development Research Science for Humanity (IDRC\&CRDI) Canada. Idrc.ca/en/ev-1-201-1-Do_Topic html.

Olokesusi, F. O (1985); Characteristics of Environmental Problems and Management Prospect in Nigeria, The Environmentalist Vol.No1.pp 23-27

World Health Organization (2004) Facts and Figures World Water Council, World Water Forum, Stanbul.

World Water Council (1997) Water Supply and Sanitation, World Water Forum, Stanbul. 